\title{
'Belmopan. A New Capital for a New Nation' State, Nation and Ethnicity at the Time of Independence
}

Bulletin of Latin American Research, https://onlinelibrary.wiley.com/doi/abs/10.1111/blar.13021

\section{Elisabeth Cunin}

Institut de Recherche pour le Développement, IRD, France Unité de Recherche Migrations et Société, URMIS, Nice, France

In Belize, a project for building a new capital emerged in the early 1960s, just after the ravages of Hurricane Hattie, which had destroyed much of the colonial capital, Belize City. According to the common narrative, Belmopan was the answer to a natural threat. But this article will show that it was also a political strategy, intended to give the country a new, modern face, the symbol of a young nation on the road to independence (1981). One of the issues of this post-colonial state is the definition of a national 'us' and the place of ethnic groups inherited from the British colonial administration's policy of 'divide and rule'. The article shows that the politicisation of ethnicity entails neither its integration in the state nor its institutionalisation by the parties, but rather the emergence of 'citizenship from below'.

Keywords: Belmopan, capital, citizenship, ethnicity, nation, state.

'The challenge for Belize is this: how do we create our own reality out of this mess of a colonial legacy? How do we give ourselves permission to think outside of the colonial box? How do we learn to value and respect our differences beyond the folkloric?' With these questions, the Belizean academic and activist Penados (2015) examines the Belizean state's refusal to recognise specific rights to ethnic minorities, in particular Mayan land rights. Belize, a British colony which became independent in 1981, found itself in a paradoxical situation: affirming sovereignty of the state at a time of globalisation of institutions, affiliation with 'transnational 
communities' and questioning of nation-states; building 'Belizeness' in a society historically characterised by migrations and a multiplicity of ethnic groups. In fact, Everitt (1987: 55) compared Belize to a 'new American neo-colony'; Duffy (2000) describes it as a 'shadow state', unable to conduct an autonomous policy; Sutherland (1998: 3) expresses doubts concerning this postmodern nation which was never modern. Thus, Belize offers an original situation for analysing the transition from colonialism to post-colonialism, the overlap between colonial and national administrations and mechanisms for asserting a national 'us' as the outcome of ethnic diversity. This article aims to understand the role of the Belizean state in the construction of a national Belizean identity and recognition of Belizean citi- zenship. I will focus on the history of Belmopan, a new capital city built in the context of the struggles for the independence.

I will be drawing on studies on the difficulties of post-colonial states. Some have even been referred to as 'failed states' (Rotberg, 2004; Sundstol Eriksen, 2011), with Haiti as a paradigmatic case (Helman and Ratner, 1992-1993). These studies point in particular to the continuity of colonial frames, the lack of economic redistribution and dependence on the outside world. Scott (1998) analysed the causes of the failure of some major twentieth-century well-intentioned state projects (in modern utopian cities like Brasilia or Chandigar, in agrarian collectivist projects, etc.) which, in the name of rationalisation and modernisation, claimed to control people and the environment for the purpose of development, but failed to achieve because of their politically oriented dimension. This theoretical framework may be useful for studying the birth of Belmopan, the capital of independent Belize. The Belizean state is probably not a 'failed state', but the history of Belmopan shows the birth of a weak state, unable to implement its policies. Belmopan was entirely planned and designed in the country's geographic centre. Plans for the city began in 1961, and construction began in 1965/1966. At the time, independence appeared to be a matter of days or weeks away, as in other British territories in the Caribbean (Jamaica in 1962, Barbados and British Guiana in 1966). The slogan 
'Belize: united, sovereign, independent. One people, one destiny' circulated everywhere. Self-government was established in January 1964 with the creation of the position of 'Premier' (Prime Minister) and a bicameral National Assembly. George Price acted as Premier of the self-government from 1964 to 1981. Considered the 'Father of the Nation', George Price and his party, the People's United Party (PUP), attempted to make Belmopan the symbol of the end of colonialism and the birth of a new country. Thus, Belmopan was viewed as the 'Capital City of the New Belize'. Yet because of Guatemala's territorial claims on Belize, independence was delayed until 1981 (Shoman, 2010), more than ten years after Belmopan was officially founded in 1970. This paradoxical situation (a capital city planned for independence without an independent state) is the starting point of this article, and the case of Belmopan will help to understand the complex process of nation-building in Belize.

Research on Belmopan converges on the project's failure and the disparity between the very ambitious political stance and the reality of an unfinished city. For Kearns (1973: 147), Belmopan represents a 'calculated gamble' in the march towards independence. Everitt highlights a political project intended to project a country's image of unity that 'can certainly be used as an example of the failure of the modernisation paradigm for development as a planning prescription' (Everitt, 1984: 143). For Davis (1991: 37), Belmopan 'was designed to embody a new nationalism, but the new-town style is a potent reminder of the colonial power that built it [...]. Most of the dreaming and planning and scheming for the project were driven by the will of one man, who wanted the city as a monument to his party and his rule'. This article develops these research findings by extending the study period to the 2000s and further emphasising the ethnic dimension of the construction of the new capital. The historiography of Belize strongly took into account the many ethnic groups in its territory and their place in the colony, then the nation. The British colony was largely reduced to Belize City, symbol of the colonial power and the formation of a 'Creole society', comprised of persons of British and African descent. The rest of the territory was occupied by native indigenous peoples (present before 
colonial settlement) or by migrant populations (Miskitos, Garifunas, refugees of the Caste War of Yucatán, East Indian workers, Confederates from the southern United States, Mennonites, etc.) on the margins of colonial society. The colonial 'divide and rule' policy instituted an ethnic organisation of the society, in which each ethnic group was defined by a culture and territory, as tangible and homogeneous entities. I will rely on works based on post-colonial studies, especially constructivist approaches (Barth, 1976) demonstrating that cultural differences originate in the reproduction of borders between ethnic groups and exchanges with the surrounding populations. For Belize, ethnic groups will not be interpreted as stable, internally focused cultural and linguistic units, but as historical constructs resulting from the colonisers' actions and reappropriated by independent states and the people themselves (Amselle and M'Bokolo, 1985). This makes it necessary to understand how and why ethnicity is - or is not - mobilised in a given situation, its social usages, representations and the strategies of actors identifying with it (Bayart, 1996).

Smith (1965) first analysed the Caribbean in terms of 'cultural pluralism' and 'plural society'. For Smith, cultural pluralism refers to cultural diversity within a given population; in the plural society, a demographic minority (the settlers, the promoters of the national project) ensures the coexistence of these different groups. His approach insists on contradictions and conflicts, in a political logic. Other scholars have analysed the region in terms of ethnicity and nation-building (Lewis, 1994; Mahabir, 1996; Moberg, 1997), to understand states' various strategies to deal with racial, ethnic and cultural divisions. In the Caribbean, 'creolisation' was a key concept to describe the cultural dimension of social and political dynamics (Sheperd and Richards, 2002). While creolisation emphasises mixing and homogenisation in their cultural dimension, Smith's pluralism insists on conflicts and contradictions in a more political way. I will retain from his approach the central role of relations of domination and distribution of power. I will continue these analyses with the ethnic boundary approach proposed by Wim- mer. Focusing on Belmopan's case, I will try to show that, in Belize, the 
non-hegemony of the Creoles, who could not impose themselves politically, economically and institutionally, does not mean the emergence of a multicultural nation, which would have institutionalised the differences in partisan logic or differential policies.

Belmopan, as the new capital of a not yet independent state, helps a better under- standing of the rationales underlying the politicisation of ethnic differences involved in nation-building projects. For Wimmer (1997: 634), "it is the institution of the modern democratic state that first raises the question who may belong to its nation, because that state embodies the idea and political practice of national sovereignty'. The state should designate the 'people' in whose name it rules over a given territory. Wimmer makes a distinction between two ethnicisation situations of the post-colonial state (1997: 635, 636). In the first case, if power is held by a population considered to be the majority in association with the state ('state people'), ethnicisation of the state and bureaucracy are immediate. One group represents the nation, while the others are considered to be minorities, leading to possible 'policies of difference'. In the second case, if no ethnic group forms a 'state people', in the absence of any demographic or political majority, ethnicisation of the state is more indirect, taking the form of clientelist practices around ethnic solidarity. My hypothesis, based on the case of Belmopan, is that Belize stands at the crossroads of these two scenarios.

Medina (1997) identifies three 'models' of political management of the country's ethnic diversity: the 'hegemonic model' in reference to the dominant status of one group, the Creoles, associated with British colonisation and having become, with independence, the reference group which tended to monopolise the national political project; the 'pluralist model', highlighting the diversity of the population resulting from historic British colonisation and successive migrations; and the 'synthetic model', emphasising the construction of an original national collective project, devised by the twentieth-century separatist movements having broken with colonial policy. These three models appear in studies on Belize. For 
some authors, 'Belizeness' is tantamount to 'Creoleness' (Shoman, 2010: 17); others insist on ethnic diversity, possibly even future 'ethnic war' (Topsey, 1987); yet others argue that this diversity has not given rise to an ethnicised political system (Bolland, 1997, 2003). My hypothesis is that, because of the coexistence of these three models of political management of ethnicity, Belize does not correspond to Wimmer's frame of analysis. The distinction made by Wimmer, when discussing the dynamics of the politicisation of ethnicity, between 'state people' and clientelist network, between hegemony of an ethnic group and shared power among several ethnic groups, seems irrelevant in the case of Belize.

First, I will look at the construction of the new capital, Belmopan. I will show that Belmopan was essentially a political project devised by George Price and the PUP to assert the Belizean state's legitimacy and credibility in the eyes of colonial authorities and the Belizean population. This project gave the Belizean state the appearance of a state and gathered the population into a single category of 'citizens', beyond ethnic differences. We shall see, though, that by relying on civil servants, the fledgling state claimed, in vain, to assert its control over the population and implicitly reinforced the association 'Belizeness' equals 'Creoleness', 'Creoles' equals 'state people', arising from colonialism. Then I will study the role of political parties, both as intermediate spaces between population and state and as loci of political construction. If, according to Bolland (1997,

2003), parties in Belize are not organised in terms of ethnic affiliation, they contribute nonetheless to the ethnic representation of society. The birth of Belmopan gave rise to differing interpretations of the Belizean nation offered by the two main parties at the time, and supported by their two daily newspapers. Thus, with reference to Wimmer, in this case the politicisation of ethnicity in a pluri-ethnic state does not entail ethnic clientelism, which would redistribute resources, but remains above all on an ideological level. Finally, I will examine the evolution of Belmopan in the 2000s. Today the town is clearly enjoying demographic growth and economic vitality. Belmopan has become a city, with 
social, economic, cultural issues, not only a capital, as a political symbol and administrative centre. I will show that a form of 'citizenship from below' is emerging and that it is more likely to build the Belizean nation than a state in search of sovereignty.

This article is based on documents from the 1960s and 1970s consulted in the National Archives of Belize in Belmopan: official Belizean government publications, experts' reports on Belmopan (planning, budget, assessment), the press, civil servants' publications, maps, photographs. These documents help identify the discourses and practices of the actors that participated in the birth of Belmopan. They are supplemented by ethnographic observations in planned Belmopan and in new suburbs (market, bus terminal, commercial centres, government offices, streets, playgrounds) looking for everyday life practices, and interviews conducted in Belmopan of eleven of the town's first inhabitants, who arrived between 1970 and 1973 and are still living in Belmopan. I focused on interviews with civil servants working for the government or for public administrations (nine) as principal actors in the construction and development of the new capital and for their narrative on Belmopan's changes; the remaining two interviewees were shopkeepers, not directly included in the official story of Belmopan (civil servants building the new nation) but who were also pioneers of Belmopan and forerunners of Belmopan's transformations in the 2000s. This fieldwork was undertaken during several stays between February 2009 and June 2013.

\section{Nation-Building and Creole Peopling}

Scott (1998) highlights four underlying principles in major projects of post-colonial states: the administrative ordering of nature and society; high-modernist ideology based on science and development; the authoritarianism necessary for bringing the project to fruition; and manipulation of civil society to provide the level social ground on which to build. In his opinion, new independent states are unable to achieve these goals. The construction of Belmopan fits perfectly in this scheme: it attests to 
a strong political will claiming to be based on modern, rational, decision-making criteria and aiming to shape the new Belizean citizen. As we shall see, however, this ambition failed: the political messages resembled government propaganda, experts' reports were extremely critical, and it was difficult to convince people to move to Belmopan.

On 31 October 1961, Hurricane Hattie destroyed much of Belize City, leaving many casualties and homeless families in its wake and throwing the country's administration into chaos. Hattie became part of a founding myth which placed the Belmopan project in a context of shared emotion, making it consensual and collective in scope and giving it a natural cause. Yet discussions on building a new capital began before the hurricane. The project had been discussed since 1957 in internal debates within the PUP, according to one of my interviewees, a militant of the PUP at that time, and in the PUP manifesto for the elections of March 1961, a few months before Hurricane Hattie (Castillo, 2000: 41). In fact, Belmopan displayed all the signs of a 'top-down' political project aiming to give life to a nation that did not yet exist, as if the foundation of a capital city justified and needed the independence of the nation. The Belmopan project was part of a political strategy intended to consecrate independence and encourage a sense of national identity transcending ethnic distinctions. For George Price, independent Belize should now overcome ethnic differences in common citizenship: 'There are no Caribs, no Creoles, no Kekchi, Maya, Spanish Indians. There are only citizens of our country in our own right' (speech given in 1962; Galvez and Greene, 2000: 89).

Several government publications were directly dedicated to Belmopan and regularly provided information to keep up with 'progress' in the new capital: The New Capital for Belize, published by the Government Printer in 1967; and Belmopan is coming to life. Come and see for yourself, published by the Belmopan Information Service for Reconstruction and Development (no date). There were also columns directly dedicated to Belmopan in broader publications like The New Belize, published from March 1971 to 
September 1973, sponsored by the Government Information Service 'to record the story of our achievements and accomplishments in the peaceful constructive Belizean Revolution'. These brochures printed practical information on Belmopan, on budget expenditure, future extension of the city, etc. Most of all, they posted the government slogan, 'Start a new life in Belmopan. A new Capital for a new Nation', and spoke directly to the new inhabitants, described as builders of the nation: 'Someone has to pioneer the New Capital and these are the people who will build a community life for others to join. Those who are proud of their Nation will want to be proud of their Capital'.

Nonetheless, this ambitious, voluntarist political discourse hardly corresponds to a birth marked by hesitation, division and contradiction. In the face of the ambitious goals and growing cost of the Belmopan project, the British government commissioned several reports from British experts (colonial officials or consultants) to validate the feasibility of the construction, monitor its progress and provide follow-up. These reports unanimously condemned a politically motivated decision, the project's disproportionate ambition, insufficient analysis of feasibility, excessive cost in view of the available budget and lack of respect for deadlines.

The budget for building Belmopan was 20 Million Belizean dollars, while the total estimate of expenses was 40 Million. From the start, Belmopan was required to adapt to a budget cut by half, which explains the fact that, even today, the city looks unfinished. The technical reports illustrate the extent to which Belmopan attested to the creation of a weak state, largely dominated by the British administration and incapable of promoting a shared national project. Political interests seem to have largely overshadowed any practical considerations of feasibility and development for the future capital, thereby revealing a discrepancy between the idealised nation and its empirical incarnation (Kearns, 1973; Everitt, 1984; Davis, 1991). 
In fact, Belmopan struggled to attract occupants. The initial projects foresaw a population of 5,000 inhabitants in 1970, a figure that should have rapidly grown sixfold to reach 30,000 inhabitants. On 1 August 1970, the city had 1500 inhabitants and had still not reached 3,000 inhabitants by 1980 (Central Statistical Office, 2001). As a political project devised by engineers, the city never actually considered the needs of its future inhabitants (there were no population surveys, unlike with the reconstruction of Corozal, following Hurricane Janet in 1955).

Belmopan's first inhabitants, construction workers building the city, and British or Commonwealth expatriots, did not linger for long. For the government, the inhabitants of Belmopan were independent Belize's future citizens. They were also expected to provide the new capital's state bureaucracy; thus, it was logical to resort to civil servants. Yet the colonial administration contributed to defining the Creoles as an ethnic group characterised by its employment as civil servants (thus limiting the access of non-Creoles) and associated with power (see colonial reports, for example by Bristowe and Wright, 1889). Implicitly, the initial populating of Belmopan with civil servants was also Creole peopling, which contradicted the inclusive discourse of George Price, celebrating the 'new Belizean citizen'.

Nonetheless, civil servants had no desire to move to Belmopan. Although Belmopan's first inhabitants personified the new nation, it cannot be said that they embodied any desirable ideal of citizenship, the town seeming to exist only thanks to government incentives granted to civil servants. It even took an ultimatum from George Price, threatening recalcitrant civil servants with losing their jobs, for the migration from Belize City to Belmopan to become a reality (Kearns, 1973: 159). The incentives granted to attract civil servants (facilitating ownership, providing aid for paying rent, moving, transport, education, etc.) ended up changing the working week: longer working days to have Saturday morning off to return to Belize City at weekends. For many, the move to the new capital meant leaving a home in Belize City, losing their social networks, 
cutting off family ties, concerns about schooling, settling in a city barely out of the ground, living with only the bare necessities and no leisure activities. 'Mud' was the first word usually uttered by those telling me their first memories of Belmopan, a city that seemed to exist 'outside civilisation'. The contrast was immense between the national project as promised and as it was experienced, between the discourse from the top and the inhabitants' practice, between collective ambition and individual hostility (see also Belmopan City Council, 2005 and Arana, 1995).

Interviews of Belmopan's first inhabitants describe a certain degree of homogeneity, the solidarity of a small close-knit community. If these new inhabitants 'made the nation', the city was largely dominated by the feeling of 'being among fellows' rather than any rationale of integration and diversity. They emphasised the inhabitants' mutual sympathy, cooperation and security, the fact that they all knew each other; memories are widely shared: mud, the ghost town at weekends, parties among friends, gardening, swimming in the river, cinema, the only restaurant (Yellow Bird), etc. References to gossip and social control are reminiscent of village life. Even 40 years later, my interviewees were generally able to list the names of all the people living along their street.

Vanguard, the civil servants' periodical published by the Public Officers Union and founded in August 1969, helps to better understand the experience of the first inhabitants of Belmopan. This publication featured many items on the role of civil servants, their national responsibility and building the nation. The issues most often raised concern for the future of Belmopan as capital of a new nation. 'The concept of the rolling Maya hills and the verdant pastures around are wonderful but not as inspiring as concerted actions defining the scope and purpose of the New Capital' (Vanguard, October 1969). They clearly reflect the confusion inherent to Belmopan - building a city, a capital and a nation - and the rather bitter reality: how can a city occupied mainly by members of the same social, economic and ethnic category of the population symbolise the nation? 'Most important, it must serve as a focus for unifying the diverse interests - cultural and economic - of the 
national "whole". In short, it is the "people" that will determine the success of the New Capital and lamentably, "people" have not been sufficiently projected in the scheme of things so far' (November 1969).

While George Price sought to transcend ethnic divisions, he implicitly associated the capital with one group: Creole civil servants. At the same time, this group did not fully support the project for a new capital and somewhat resisted submission to state control. It did not personify what Wimmer refers to as the 'state people' which was intended to contribute to creating open ethnicisation of the state.

\section{Political Parties: Non-institutional Ethnicisation of Political Antagonisms}

Bolland demonstrated that Belizean political parties are not structured on an ethnic base and 'cut across ethnic group boundaries' (Bolland, 2003: 211). In some situations, however, the 'salience' of ethnicity (Lyman and Douglass, 1973) is apparent in political parties' discourse. This is true for the construction of Belmopan which, by affecting the national definition of nation and national 'us', polarises partisan antagonisms around the issue of identity and belonging. According to Wimmer's scheme, Belize is similar to his second scenario of ethnic clientelism, without, however, achieving partisan and state institutionalisation of ethnic difference. Power is not allocated on the basis of ethnicity, thereby preventing redistribution of the state's (limited) resources according to an ethnic rationale. Yet, as we will see, the state is also permeated with representations of the nation grounded in an ethnic dimension.

Far from embodying national unity or a consensual march towards independence, the birth of Belmopan was marked by ideological confrontation between the two main political parties at the time, the PUP and the NIP (National Independence Party, ancestor of today's UDP, United Democratic Party). The NIP opposed what it considered the PUP's Central American orientation and was seen as 
a Creole party (Bolland, 1997: 277-278). I will now examine the discourse of both parties, through the study of the two publications directly linked to them, The Belize Times (PUP) and The Belize Billboard (NIP). I will focus on the crucial period from the end of construction works in Belmopan to the inauguration of the city and the arrival of its first inhabitants: 1969, 1970, 1971.

To promote the city, certain safety aspects were highlighted (hurricanes), along with economic development (agriculture, industry), but especially the fact that the capital, being at the centre of the country, should benefit the entire population. 'No true development can take place on the fringes. It must be in the heart' (Belize Times, 13 March 1970). Such rebalancing entails something problematic for the opposition: calling into question the hegemony of Belize City. In fact, the country was then almost exclusively centred on Belize City, where governmental institutions, economic activities and the majority of the population were all concentrated. To justify this geographic relocation, The Belize Times did not hesitate to associate it with reinterpretation of national his- tory. The Battle of Saint George's Caye, the founding myth of Belize, commemorating the victory over the Spanish by the British accompanied by slaves and descendants of free Africans, was the subject of a critical revision. It did not sufficiently embody a nation made up not only of Creoles (descendants of British and Africans), but also of Garifunas, Chinese, Mayas, East Indians, Mennonites, Mestizos (descendants of Indians and Spaniards), etc. Thus, Belmopan symbolised not only the pending national project; it also implicitly challenged the dominant status of Creoles as sole representatives of the future nation.

The newspaper proposed to define 'What is a nation:' 'The Battle of St. George's Caye is an essential part of our national celebration [... ], all elements of the settlement, black and white, slave and free fought side by side as equals [ ... ]. But the Battle of St. George's Caye is not the sum total of our nationalism. Ancient Maya settlements in our land connect us to the pre-Columbian heritage of America. Spanish and Indian settlers have developed sugar and 
other agricultural industries in our land. Many immigrants from all over the world have helped to develop this country' (Belize Times, 5 August 1970). The very name Belmopan, formed with the names Belize and Mopan, referred to a river and the Mopan Maya population. The architectural style of government buildings inspired by Maya motifs attested to the will to impose a new national myth highlighting Belize's pre-colonial past by focusing on the indigenous presence, 'for- gotten' in the colonial narrative associated with Creole society. Travelling to England to convince the government to finance construction of the new capital, George Price is said to have defended his project by anchoring it in the Maya past, minimised until then.

In The Belize Billboard, this rewriting of history was interpreted by NIP leaders as a direct challenge to the role of Creoles in local history. Thus, tension between the PUP and NIP touched on the very definition of national history and the place of ethnic groups. For the NIP, it was a matter of reviewing the official history of Belize, celebrating the Battle of Saint George's Caye. 'Belize City is the oldest city in our country, founded by the first settlers themselves. The history and personality of our country is stamped on the face of the city' (Belize Billboard, 30 August 1970).

The political conflict between the PUP and NIP crystallised around opposition defined in geographic and ethnic terms between Mestizos and Creoles. In fact, the NIP and Belize Billboard reproached the government and the PUP with favouring people of Maya and Hispanic descent while marginalising those of African descent whose spokespersons they became. For The Belize Billboard, while Mestizos took over the economy (farmers in the north, fishermen on the islands, rice farmers in the south), Black people had to pre- serve political power acquired from the colonial authority (Belize Billboard, 11 August 1970). The threat of a Guatemalan invasion of the country was then used to reassert this Caribbean affiliation, and even maintain ties with Great Britain. The newspaper also underscored the fact that, not only was Belmopan located at the centre of the country, but most of all it brought its 
centre of gravity closer to the border with Guatemala. An editorial was titled 'Belmopan: 30 Miles to Guatemala: Is it an Accident?' (Belize Billboard, 30 July 1970).

These conflicting visions of the nation reached the height of their expression in the rivalry between Belize City and Belmopan. The competition between the two cities refers in fact to the challenges evoked above around the very definition of the nation, in particular in its ethnic dimension: on the one side, Belize City was viewed as a Creole city, for both its demographic makeup and its history, and, on the other, Belmopan was considered as a capital reflecting the country's diversity. Elections were held in 1969, just before completion of the construction of Belmopan. While the PUP published a manifesto evoking the new capital as an essential reality, the NIP was committed to redesigning Belize City and called on mobilisation around 'a modern Belize City' (Belize Billboard, 12 April 1969). It must also be recalled that, in the late 1960s and early 1970s, the 'Hat- tie effect' was forgotten: the relative consensus of 1961-1963 to move the government headquarters gave way to a new dynamics to promote the development of Belize City. Insurance made it possible to rebuild the city and rehabilitation programmes for Belize City (water, sewage, port) were set up, diverging from the emergency plans adopted right after Hattie (Everitt, 1986). Furthermore, the investments made in Belmopan were viewed as a loss of resources for Belize City as the initial enthusiasm for Belmopan wore off. In 1970, an editorial in The Belize Billboard (11 August 1970) entitled The Orphan City expressed concern: '332 years after the first settlement in 1638, Belize City has ceased to be the capital of British Honduras' and denounced George Price, 'now sitting in the Belmopanian heights [where] he can issue orders to the subject people through the rubberstamp Ministers surrounding him'. The PUP's argument was turned around: Belmopan did not ensure development throughout the country, but gained in wealth to the country's detriment. 'Belmopan is a parasite city latched onto the body of a poor and destitute country. It cannot survive unless it feeds on the resources of the rest of the country' (Belize Billboard, 23 August 1970). 
Far from George Price's pan-ethnic vision, Belmopan succeeded in crystallising the antagonism between Belize's two main parties and contributed to build an ethnicised representation of the nation. At the same time, the parties' lack of ethnic structuring does not open the way for institutional political expression to such ethnicisation and for Wimmer's scheme of clientelist ethnic practices. As I will show in the last part, it is in this context of informality that 'citizenship from below' seems to arise, far from regulation by the state and partisan ideological divides.

\section{Building a Multicultural Citizenship from Below}

Using the notion of 'citizenship from below' in Argentina and Peru, Jelin (1993) emphasises the disparity between the formality of the state and citizens' practice. She suggests analysing the meaning of the nation-state in terms of the daily lives of social actors, not as objects of public policy, but rather as subjects of national construction. In Belize, the weakness of the state may deter militant forms of mobilisation. Such citizenship refers rather to the idea of 'small country' proposed by Hannerz and Gingrich (2017: 4): 'countries are a significant kind of arena of social life, and, in our times, people's understandings of who they are and what life is like are not to small extent anchored in such arenas' (Hannerz and Gingrich, 2017: 4). Thus, local, everyday, ordinary citizenship developed alongside more formal citizenship, created by the state through a nation-building rationale. Wilk (2017), in his contribution to the book by Hannerz and Gingrich, considers Belize to be 'a small country, not a nation'. He highlights the intimate nature of social relations, the density of interconnections, the impossibility of anonymity, the informality and personalisation of institutional relations in Belize. Even governmental power generally takes the form of someone you know. The impression that the 'nation is just a big village' (Wilk, 2017: 240) is particularly applicable to Belmopan. 
Today, Belmopan seems to be playing its role, if not of national integration, at least as a meeting place between the country's regions and population groups. 'Without a past', the city is not part of the 'divide and rule' heritage and confinement of an ethnic group to a given territory. Inés Sánchez, a descendant of Mexicans fleeing the Caste War of Yucatán to Belize in the nineteenth century, and as such considered as a 'Mestizo', was one of the first inhabitants of Belmopan. He volunteered to live in the city at a time when it had great difficulty finding inhabitants. One of the few civil servants who was not Creole in the 1970s, he had responsibilities within the Ministry of National Education. In fact, beyond the lack of shops and leisure areas, beyond its isolation, he found Belmopan far more welcoming than Belize City, precisely because everyone could have a place there, while he felt like a foreigner in Belize City (interview, 25 March 2009). Originally from the North of the country, too far for him to commute regularly, he embodied this figure of the 'pioneer' praised by George Price, who settled in Belmopan at the birth of the city and still resides there today. Inés Sánchez came to Belmopan as a civil servant, but he became a citizen of Belmopan thanks to the openness and hospitality of the city.

The Belmopan project was not just a myth or a political tool, but, in some cases, also promoted a trajectory of social ascension and national integration of these Belizean Mestizos, along with Mayas, Garifunas, Chinese, etc. As Chief Education Officer, Inés Sánchez drafted many texts on the need to teach national history from a Belizean point of view, associating himself directly with this 'pacific revolution' and construction of the nation (Sánchez, 1977).

It was not until the late 1980s, with the arrival of Central American migrants, that the population of Belmopan began to grow $(13,351$ inhabitants according to the 2010 census), the city spread (with the new suburbs of Salvapan, San Martin, Maya Mopan, Las Flores) and the economy diversified (farming, construction, cleaning, shops). As we have seen, the first inhabitants, mainly Creole civil servants from Belize City, long hesitated to settle in Belmopan in the 1970s, preferring to commute between Belize City and 
Belmopan. The 1980s were marked by 'massive' migration (in proportion to Belize's low demographic density) of Central American refugees fleeing their countries' political and economic plight. The number of refugees was estimated between 30,000 and 50,000 for a total population of 185,970 in 1991 (Collins, 1995). Belmopan and its surroundings (the refugee camp of Valle de Paz is some twenty kilometres away) became home to a large part of this population, itself lumped together in administrative practice and day-to-day interaction under the generic term Mestizo. The 1991 census showed the Mestizo population was larger than the Creole population (43.6 percent Mestizo, 29.8 percent Creole). Several pessimistic interpretations were made of this census, openly referring to a 'Latin threat' which could challenge Belize's 'Creole identity'. The extensive ambiguous nature of the Mestizo category dramatised what was perceived as the country's plunge into the Central American space.

Nevertheless, Central American migrants brought life to a city that had until then been nothing more than an unattractive periphery to Belize City. Their farming activities and the sale of their products in the market of Belmopan helped them link the city with its surroundings; as construction workers, carpenters and plumbers, they contributed to Belmopan's urban growth. On an administrative level, the city also shed its specific status: the Reconstruction and Development Corporation (Recondev), the organisation entrusted with the construction of Belmopan, took over management of the city from its birth until 2000. Recondev's role has often been criticised, for its lack of resources and personnel, as well as its practices characterised by opacity and political favours. This situation was visibly quite popular since it made it possible not to pay local taxes. Consequently, Recondev had no other resources to invest in the city than those from property rental and government funds. Belmopan's ambiguous status, between village, city and capital, was reflected in its very management: it was not until 2000 that it achieved administrative autonomy and organised its own municipal elections, after having been run for 30 years by a paragovernmental organisation. 
Central American migrants were well accepted, with relatively easy access to housing and land, health and educational services, residents' status and even nationality (Palacio, 1990), in a context of economic (need for manpower) and demographic (population increase) pragmatism, not without certain political interests (future electors). Today, the children of these refugees are Belizean, speak English in school, Creole in the street and Spanish in the home. They retain ties with their countries of origin through remesas (economic remittances), visits to the family as well as the arrival in Belize of new migrants, whose constant flow has now slowed and receives less media coverage today.

Belmopan has become, in demographic terms, the country's third city, following Belize City and San Ignacio/Santa Elena (17,878 inhabitants). While Belize City suffers from rising crime and a high urban density, Belmopan is reputedly safe, free of traffic jams and with affordable land for housing. Today, the city is the country's political and academic centre. The transfer of most teaching of the University of Belize from Belize City to Belmopan and the building of a new campus in the first decade of the twenty-first century thus favoured the arrival of many students and teachers, a movement that itself triggered completely new dynamics: housing needs, demand for cultural and sporting activities, emergence of entertainment venues, increased transport, etc. The standardised houses of the 1970s and 1980s have given way to a more complex urban landscape, attesting to the city's different stages of development and the presence of a more diversified population: several small cubic two-room houses were personalised by adding verandas, garages, another storey; the large homogeneous lawns were divided into tidy little gardens; outlying districts developed independently of any architectural planning (wood houses, parcels of different sizes, luxury homes).

Belize has become a hub between Central America and the United States or the Maya Riviera in neighbouring Mexico, whose touristic activities attract considerable man- power from Central America. And Belmopan is now located at the crossroads of these multiple 
circulations in Belize. The capital is at the junction of all roads crossing the territory from north to south and east to west. The construction of a diversion on the Northern Highway now makes it possible to reach Belmopan directly from the north (then the south and west of the country) without going through Belize City. Thus, one can cross paths in the centre of Belmopan with people from all over the country belonging to all ethnic groups, here to settle an administrative issue in one of the ministries, sell farm products at the market or register for university courses.

Finally, the successive migratory waves tended to reinforce the feeling of belonging among those who were already there, identification with a local 'us'. The first generations of Central American migrants ostensibly differentiated themselves from newcomers, speaking Creole, running small shops, investing over the long term in houses. More than jus soli (right of the soil) or jus sanguinis (right of blood), more than a formal administrative procedure, it is integration in the local community and participation in social life that grants citizenship (Herzog, 2006). Belmopan has become a normal town, and is not anymore the utopian capital of a dreamed of country; the feeling of citizenship of its inhabitants is not the result of their relation to the state but of their belonging to an ordinary place.

\section{Conclusion}

With Belmopan, we were able to analyse simultaneously the weakness of the state and the limitations to the politicisation of ethnicity. Wimmer's two scenarios do not apply to Belmopan: Creoles do not form a 'state people' directly associated with the state; power and resources are not distributed according to a rationale of ethnic clientelism. This can likely explain that, unlike the cases studied by Wimmer, construction of the state did not give rise, until recently, to ethnic conflicts in Belize. In fact, the politicisation of ethnicity is primarily ideological, even rhetorical and strategic, in the rivalry between the two main national parties, the PUP and NIP, then UDP. It does not give way to ethnically 
oriented policies. Expressions of ethnicity take on an informal commonplace form in everyday interaction, the coexistence of individuals of multiple origins and the continued integration of new migrants, as attested by the transformation of Belmopan in the 2000s. Because of the failure of a strictly planned and controlled capital project, the inhabitants of Belmopan built their citizenship 'from below', as a form of everyday democratic practice, both plural and contextual.

Nonetheless, the question raised by Penados in the introduction to this article is increasingly relevant. What place is there for ethnicity in a post-colonial state? The lack of politicisation of ethnicity by/in the state and parties led, in the 1990s and 2000s, to the emergence of ethnic social organisations: Toledo Maya Cultural Council, National Garifuna Council, National Kriol Council, etc. The challenge was that of their integration 'into a culturally pluralistic nation' (Bolland, 2003: 219). Regarding Mayan territorial claims, the intervention of an outside third actor, the Inter-American Commission on Human Rights, clearly showed that dialogue between the Belizean state and ethnic organisations did not work (Minority Rights Group International, 2016). The weakness of the state avoided ethnic polarisation of the bureaucracy and society, but simultaneously the fiction of a modernising and developing state, acting on behalf of the population, prevented a direct acknowledgment and political management of plurality.

\section{References}

Amselle, J.-L. and M'Bokolo, E. (eds.) (1985) Au cœur de l'ethnie. Ethnie, tribalisme et etat en Afrique. La Découverte: Paris.

Arana, F. B. (1995) It Used to be that ... Volume II. BRC Printing Ltd: Benque Viejo del Carmen.

Barth, F. (dir.) (1976) Ethnic Groups and Boundaries: The Social Organization of Cultural Difference. George Allen and Unwin: London. 
Bayart, J. F. (1996) L'illusion identitaire. Fayard, coll. L'espace du politique: Paris.

Bolland, N. (1997) Struggles for Freedom: Essays on Slavery, Colonialism and Culture in the Caribbean and Central America. Angelus Press: Belize City.

Bolland, N. (2003) Colonialism and Resistance in Belize: Essays in Historical Sociology. Cubola Books: Benque Viejo.

Bristowe, L. W. and Wright, P. (1889) The Handbook of British Honduras, 1888-1889. Blackwood: Edinburgh and London.

Castillo, R. (2000) 'Building Belmopan' in F. Galvez and E. Greene (eds.) George Price. Father of the Nation of Belize. Ion Media: Belize, 41-48.

Central Statistical Office (2001) Belize. Abstract of Statistics 2001. Central Statistical Office, Ministry of Finance: Belmopan.

Collins, C. O. (1995) 'Refugee Resettlement in Belize'. Geographical Review 85(1): 20-30.

Davis, S. E. (1991) 'Designing Nationalism: Belmopan, Belize'. Landscape 31: 36-48. Duffy, R. (2000) 'Shadow Players: Ecotourism Development, Corruption and State Politics in Belize'. Third World Quarterly 21(3): 549-565.

Everitt, J. C. (1984) 'Belmopan, Dream and Reality: A Study of the Other Planned Capital in Latin America'. Revista Geografica 99: 135-144.

Everitt, J. C. (1986) 'The Growth and Development of Belize City'. Journal of Latin American Studies 18(1): 75-111.

Everitt, J. C. (1987) 'The Torch Is Passed. Neocolonialism in Belize'. Caribbean Quarterly 33(3/4): 42-59.

Galvez, F. and Greene, E. (2000) George Price. Father of the Nation of Belize. Ion Media: Belize.

Hannerz, U. and Gingrich, A. (eds.) (2017) Small Countries. Structures and Sensibilities. University of Pennsylvania Press: Philadelphia.

Helman, G. B. and Ratner, S. R. (1992-1993)) 'Saving Failed States'. Foreign Policy 89: 3-20.

Herzog, T. (2006) vecinos y extranjeros. hacerse español en la edad moderna. Alianza Editorial: Madrid. 
Jelin, E. (1993) ‘¿cómo construir ciudadanía? una visión desde abajo'. European review of Latin American and caribbean studies/revista Europea de estudios latinoamericanos y del caribe 55: 21-37.

Kearns, K. C. (1973) 'Belmopan: Perspective on a New Capital'. Geographical Review 63(2): 147-169.

Lewis, L. (1994) 'Ethnicity and Nation-Building: The Surinamese Experience'. Caribbean Quarterly 40(3-4): 72-83.

Lyman Stanford, M. and Douglass William, A. (1973) 'Ethnicity: Structure of Impression Management'. Social Research 40(2): 344365.

Mahabir, K. (1996) 'Whose Nation Is this? The Struggle over National and Ethnic Identity in Trinidad and Guyana'. Caribbean Studies 29(2): 283-302.

Medina, L. K. (1997) 'Defining Difference, Forging Unity: The CoConstruction of Race, Ethnicity, and Nation in Belize'. Ethnic and Racial Studies 20(4): 757-780.

Minority Rights Group International (2016) 'Belize: Advocating Maya People's Rights to Land'. [WWW document]. URL https://minorityrights.org/law-and-legal-cases/maya-__ in-belize/ [accessed 2 November 2019]

Moberg, M. (1997) Myths of Ethnicity and Nation: Immigration, Work, and Identity in the Belize Banana Industry. The University of Tennessee Press: Knoxville.

Palacio, J. (1990) 'Socioeconomic Integration of Central American Immigrants in Belize'. SPEAReports 2: 5-25.

Penados, F. (2015) 'Reflections on the Recent Developments in Toledo', blog From Belize with Hope, [WWW document]. URL http://frombzwithhope.blogspot.fr/2015/06/ reflections-on-recentdevelopments-in.html?view=mosaic, 26 June 2015 [accessed 2 November 2019]

Rotberg, R. (2004) When States Fail: Causes and Consequences. Princeton University Press: Princeton.

Sanchez, I. (1977) 'Belizean History: Its Role in a Cultural Revolution'. Belizean Studies 5(5). 
Scott, J. C. (1998) Seeing like a State. How Certain Schemes to Improve the Human Condition Have Failed. Yale University Press: New Haven and London.

Sheperd, V. and Richards, G. L. (eds.) (2002) Questioning Creole. Creolisation Discourses in Caribbean Culture. Ian Randle Publishers: Kingston, James Currey Publishers: Oxford.

Shoman, A. (2010) Reflections on Ethnicity and Nation in Belize. Cuaderno de Trabajo No. 9, Document de travail No. 9. Proyecto Afrodesc/ Eurescl: México.

Smith, M. G. (1965) The Plural Society in the British West Indies. University of California Press: Berkeley.

Sundstol Eriksen, S. (2011) "'State Failure' in Theory and Practice: The Idea of the State and the Contradictions of State Formation"'. Review of International Studies 37(1): 229-247.

Sutherland, A. (1998) The Making of Belize. Globalization in the Margins. Bergin and Gar- vey: Westport. The Statistical Institute of Belize.

Topsey, H. (1987) 'The Ethnic War in Belize'. SPEAR Ethnicity and Development: 1-5.

Wilk, R. (2017) 'A Country but Not a Nation' in U. Hannerz and A. Gingrich (eds.) Small Countries. Structures and Sensibilities. University of Pennsylvania Press: Philadelphia,236-249.

Wimmer, A. (1997) 'Who Owns the State? Understanding Ethnic Conflict in Post-Colonial Societies'. Nations and Nationalism 3(4): 631-665.

\section{Archives}

Belmopan Information Service for Reconstruction and Development (n.d.) Belmopan Is Coming to Life. Come and See for Yourself. Miscellaneous, part. 1, MC 700, Archives of Belize, Government Printer: Belmopan.

Dimond, F. M. (n.d.) Emergency Plans for the New Capital City of British Honduras. Miscellaneous, part. 1, MC 561, Archives of Belize, Belmopan.

Government Information Service (1967) The New Capital for Belize. Published by the Government Information Service, Belize 
City, on behalf of the Reconstruction and Development Corporation. February. Printed by the Government Printer. Miscellaneous, part. 1, MC 708, Archives of Belize, Belmopan.

Grier, A. M. and Prosser, A. R. G. (n.d.) The Move to the New Capital. Miscellaneous, part. 1, MC574, Archives of Belize, Belmopan.

Her Majesty's Stationery Office (1959) Colonial Report. British Honduras 1957. Her Majesty's Stationery Office: London. AR/ 957/3, Archives of Belize, Belmopan.

Ministry of Overseas Development (1974) Belmopan. An ex-post Evaluation. Oldacres and Co Ltd: London. Miscellaneous, part 1, MC-2379, Archives of Belize, Belmopan. Reconstruction and Development Corporation (1963) Notice of the 10th Board Meeting. 14 June 1963, Legislative Assembly Gallery. Miscellaneous, part 1, MC 613, Archives of Belize, Belmopan.

Scott and Wilson, Kirkpatrick and Partners, Preece, Cardew and Rider, Norman and Daw- barn, Widnell and Trollope (1963) Report on Proposed New Capital for British Hon- duras. Archives of Belize, Belmopan.

The Belmopan City Council, Belize Archives Department and George Price Centre for Peace and Development (2005) Pioneers of Belmopan. Archives of Belize, Belmopan.

\section{Newspapers}

The Belize Times, from 1969 to 1971.

The Belize Billboard, from 1969 to 1971. Vanguard, 1969. 